\title{
Rekonstruksi Penyidik Pegawai Negeri Sipil dan Jaksa Penuntut Umum dalam Tahap
}

\section{Penyidikan}

\author{
Priyambudi \\ budi_jpu@yahoo.co.id \\ Kejaksaan Republik Indonesia
}

\begin{abstract}
Abstrak
Pemerintah melalui criminal policy membuat peraturan dan menuangkannya kedalam berbagai Undang-undang sehingga terdapat begitu banyak Undang-undang yang berlaku dan yang harus mampu ditegakkan oleh para aparatur Negara. Rumusan masalah pada penulisan kali ini adalah mengkaji kedudukan Penyidik PNS, Penyidik Polri dan Penuntut Umum. Tujuan penulisan ini adalah untuk menggambarkan bahwasanya dalam tahap penyidikan yang selama ini dilaksanakan, belum cukup efektif untuk menjamin penegakan hukum guna mendukung efektifitas berjalannya sistem peradilan pidana menuju tercapainya asas peradilan yang murah, cepat dan sederhana. Realitas Indonesia yang memiliki banyak diterbitkan Peraturan Perundang-undangan yang bersifat Administrative Penal Law, yang ternyata lebih sering menjadi macan kertas saja. Hal ini dikarenakan penegakan Undang-undang tersebut justru jarang dilakukan oleh PPNS yang diberi wewenang penyidikan oleh Undang-undang itu sendiri, namun lebih sering menunggu dilakukan oleh penyidik Polri yang jumlahnya masih bisa dibilang terbatas jika dibandingkan dengan luas wilayah Negara kita Mengenai kedudukan Penyidik PNS, Penyidik Polri dan Penuntut Umum, maka yang sebaiknya dilaksanakan untuk dapat menjamin terlaksananya penegakan hukum secara efektif menuju tercapainya asas peradilan yang murah, cepat dan sederhana, antara lain JPU berperan sebagai sebagai pihak yang memimpin penyidikan dan mengarahkan jalannya penyidikan (koordinator dan supervisor), antara lain : menentukan pasal apa saja yang dapat disangkakan kepada tersangka; siapa saja yang dapat dijadikan sebagai tersangka; alat bukti apa saja yang harus dikumpulkan sebagai pembuktian.
\end{abstract}

Kata Kunci : Jaksa Penuntut Umum, Rekonstruksi Hukum, Penyidikan, Penyidik

\begin{abstract}
The Government through criminal policy makes regulations and pour them into various laws so that there are so many laws that are applicable and that must be enforceable by the State apparatus. The problem formulation in this time is reviewing the position of CIVIL investigator, police investigator and public prosecutor. The purpose of this writing is to describe that in the phase of the investigation that has been implemented, is not yet
\end{abstract}


effective enough to ensure the law enforcement to support the effectiveness of the system of criminal justice to achieve the principle The judiciary is cheap, fast and simple. The reality of Indonesia which has many published legislation which is Administrative Penal Law, which turned out to be more often a paper tiger. This is because the enforcement of the law is rarely done by PPNS who are given the authority of the investigation by the law itself, but more often the wait is done by the number of police investigators who can still be limited if Compared to the area of our country regarding the position of CIVIL investigators, police investigators and prosecutors, then that should be implemented to be able to ensure the implementation of law enforcement effectively towards the achievement of a cheap judicial principle, Fast and simple, among others, JPU serves as the lead party investigation and directs the course of Investigation (Coordinator and Supervisor), among others: Determining which chapters can be sent to the suspect; Anyone who can be used as a suspect; What evidence should be collected as proof.

Key words: Public Prosecutor, Legal Reconstruction, Investigation, Investigator

\section{A. Pendahuluan}

Fungsi hukum sebagai alat pengendalian sosial, menurut Achmad Ali $^{1}$ ada hal yang sangat perlu diketahui, yaitu :

1. Fungsi hukum sebagai alat pengendalian sosial, dapat dijalankan oleh suatu kekuasaan terpusat yang dewasa ini berwujud kekuasaan Negara, yang dilaksanakan oleh "the ruling class" tertentu atau suatu elit. Hukum biasanya berwujud hukum tertulis atau perundang-undangan.

2. Fungsi hukum sebagai alat pengendalian sosial dapat juga dijalankan sendiri dari "bawah" oleh masyarakat itu sendiri. Hukumnya biasanya terwujud tidak tertulis atau hukum kebiasaan.

Terlaksana atau tidak terlaksananya fungsi hukum sebagai alat pengendalian sosial ditentukan oleh dua hal :

1. Faktor aturan hukumnya sendiri,

2. Faktor pelaksana (orang) hukumnya.

Jadi bekerjanya hukum bukan hanya merupakan fungsi perundang-undangan belaka, melainkan juga aktivitas birokrasi pelaksanaannya. Seiring dengan

\footnotetext{
${ }^{1}$ Achmad Ali, Menguak Tabir Hukum, Jakarta : Gunung Agung, 2002 hlm. 89.
} 
perkembangan jaman dan dinamika masyarakat maka kriminalitas pun semakin canggih dan berkembang kualitas dan kuantitas modus operandinya, sehingga hukum beserta aparat penegak hukum dikhiaskan berjalan tertatih-tatih mengikuti perkembangan kriminalitas. Untuk mengantisipasi hal tersebut pemerintah melalui criminal policy membuat peraturan dan menuangkannya kedalam berbagai Undangundang sehingga terdapat begitu banyak Undang-undang yang berlaku dan yang harus mampu ditegakkan oleh para aparatur Negara.Dengan semakin canggih dan berkembang kualitas serta kuantitas modus operandi berbagai tindak pidana maka harus diimbangi dengan peningkatan kualitas dan kuantitas aparat penegak hukumnya. Polisi sebagai institusi yang oleh Undang-undang diberi wewenang paling luas sebagai penyidik dituntut harus mampu mengikuti laju perkembangan tersebut supaya berbagai Undang-undang yang saat ini telah banyak diundangkan dapat ditegakkan apabila terjadi pelanggaran sehingga tidak hanya menjadi macan kertas saja. Namun pada kenyataannya kualitas dan kuantitas penyidik Polri belum sepenuhnya dapat mengemban tugas, tanggung jawab dan wewenangnya secara maksimal untuk menegakkan berbagai Undang-undang yang telah berlaku, apalagi sekarang ini sudah banyak sekali Undang-undang yang mengatur berbagai bidang administratif dan mempunyai sanksi pidana (administrative penal law).

Dewasa ini di Indonesia banyak diberlakukan Undang-undang tersendiri diluar KUHP, seperti UU Tindak Pidana Ekonomi; UU Pemberantasan Tindak Pidana Korupsi; UU Narkotika; UU Antiterorisme; UU Pencegahan \& Pemberantasan Perusakan Hutan; dan banyak lagi perundang-undangan administrasi yang bersanksi pidana semisal UU tentang Perbankan; UU Telekomunikasi; UU Pasar Modal; UU tentang Hak Cipta, Merk dan Paten; UU tentang Kesehatan,; UU tentang Perkeretaapian; UU Kehutanan; UU tentang Konservasi Sumber Daya Alam; UU Perikanan; UU tentang Cagar Budaya; UU tentang Lingkungan Hidup; UU tentang Perlindungan Konsumen; UU tentang Pencegahan Praktik Monopoli dan Persaingan 
Usaha Tidak Sehat; dan sebagainya. Selain itu makin bertambah pula kriminalisasi alias adanya berbagai tindak pidana yang baru, contohnya adalah UU Pemberantasan Tindak Pidana Perdagangan Orang; UU Pemberantasan Tindak Pidana Pencucian Uang dan UU tentang Informasi dan Transaksi Elektronik. Selain itu masih ada lagi Rancangan Undang-undang baru yang nantinya akan semakin menambah kompleksitas hukum pidana, contohnya RUU mengenai Cyber Crime (Kejahatan Dunia Maya). Mempelajari hukum pidana dalam undang-undang tersendiri itu tentu memerlukanwaktu dan pikiran yang banyak, serta tentu saja dibutuhkan skill intelektualitas dari penyidik yang Sarjana Hukum dan Sarjana Hukum yang penyidik.Hal ini tentunya semakin menambah berat tugas \& tanggung jawab yang diemban para penegak hukum, khususnya Penyidik Polri sebagai institusi yang mempunyai wewenang sebagai penyidik tunggal dan pertama kali langsung berhadapan dengan masyarakat.

Dikawatirkan banyaknya Peraturan Perundang-undangan yang bersifat Administrative Penal Law lebih sering menjadi macan kertas saja. Hal ini dikarenakan dalam penerapan dan penegakan Undang-undang tersebut justru jarang dilakukan oleh PPNS yang diberi wewenang penyidikan oleh Undang-undang itu sendiri namun lebih sering menunggu dilakukan oleh penyidik Polri yang jumlahnya terbatas jika dibandingkan dengan luas wilayah Negara kita, dengan kompleksitas dan tantangan tugas, dengan kendala intern dan ekstern serta dengan begitu banyaknya Administrative Penal Lawdewasa ini. Keberadaan bintara penyidik pembantu tentu kurang dapat terjamin kualitasnya dalam menghadapi segala kompleksitas tantangan tersebut. Sinyalemen itu dapat dilihat melalui banyaknya berkas perkara yang bolak-balik dari Kepolisian dan Kejaksaan karena Jaksa menganggap berkas hasil penyidikan belum lengkap atau belum memenuhi syarat untuk dilanjutkan kepada proses hukum selanjutnya, yaitu tahap penuntutan. 
Pada saat sekarang muncul pendapat yang mengatakan :Statutes tend to be created accordingly by experts for experts. Akibatnya statutory are complex.Hukum dibuat oleh orang ekspert untuk orang ekspert. Tapi barangkali bukan itu saja permasalahan yang menyebabkan undang-undang semakin kompleks :

1) Kehidupan sosial, ekonomi, politik dan perubahan manusia yang hendak diatur, juga semakin kompleks sesuai dengan perkembangan dan pertumbuhan yang mereka lalui;

2) Dalam kondisi yang seperti itu, undang-undang yang hendak mengatur tata kehidupan mereka pun harus disesuaikan dengan rumusan yang kompleks. Mau tidak mau ketentuan undang-undang yang disusun menjadi kompleks. ${ }^{2}$

Kualitas penegakan hukum yang dituntut masyarakat saat ini bukan sekedar kualitas formal, tetapi terutama kualitas penegakan hukum secara materiil/substansial seperti terungkap dalam beberapa isu sentral yang dituntut masyarakat, antara lain :

1. Adanya perlindungan Hak Asasi Manusia

2. Tegaknya nilai kebenaran, kejujuran, keadilan dan kepercayaan antar sesama

3. Tidak adanya penalahgunaan kewenangan/kekuasaan

4. Bersih dari praktek pilih kasih, KKN dan mafia peradilan

5. Terwujudnya kekuasaan kehakiman/penegakan hukum yang merdeka dan tegaknya kode etik/kode profesi

6. Adanya penyelenggaraan pemerintahan yang bersih dan berwibawa ${ }^{3}$.

Banyak faktor yang mempengaruhi dan menentukan kualitas penegakan hukum.Faktor itu dapat berupa kualitas individual (SDM), kualitas instansional/struktur hukum (termasuk mekanisme tata kerja dan manajemen), kualitas sarana/prasarana, kualitas perundang-undangan (substansi hukum), dan kualitas kondisi lingkungan (sistem sosial, ekonomi, politik, budaya, termasuk budaya hukum

\footnotetext{
${ }^{2}$ Yahya Harahap, Pembahasan Permasalahan dan Penerapan KUHAP, Jakarta : Sinar Grafika, 2004. hlm. 13.

${ }^{3}$ Barda Nawawi Arief, Beberapa Aspek Kebijakan Penegakan dan Pengembangan Hukum Pidana, Bandung : PT. Citra Aditya Bakti, 1998. hlm. 66.
} 
masyarakat).Dengan demikian, upaya peningkatan kualitas penegakan hukum harus mencakup keseluruhan faktor kondisi/kausa yang mempengaruhinya. Dari sekian banyak faktor itu wajar apabila lembaga pendidikan lebih menekankan perhatian pada masalah kualitas SDM yang menjadi sumber utama dari proses penegakan hukum. Kualitas SDM inilah yang banyak mendapat sorotan tajam di era reformasi dewasa ini ${ }^{4}$.

\section{B. Rumusan Masalah}

1. Seberapa jauh kedudukan PPNS, Penyidik Polri dan Penuntut Umum dalam tahap penyidikan yang selama ini dilaksanakan dapat menjamin penegakan hukum secara konsekuen serta mendukung efektifitas berjalannya sistem peradilan pidana menuju tercapainya asas peradilan yang murah, cepat dan sederhana?

2. Kedudukan PPNS, Penyidik Polri dan Penuntut Umum bagaimanakah yang sebaiknya dapat dilaksanakan sebagai rekonstruksi dalam tahap Penyidikan untuk dapat menjamin terlaksananya penegakan hukum secara konsekuen serta dapat mendukung berjalannya sistem peradilan pidana menuju tercapainya asas peradilan yang murah, cepat dan sederhana secara lebih efektif?

\section{Pembahasan}

\section{Kedudukan PPNS, Penyidik Polri dan Penuntut Umum}

Sebagaimana kita ketahui bahwa KUHAP telah secara jelas dan tegas mengatur wewenang penyidik Polri (plus penyidik pembantu), penyidik pegawai negeri sipil (PPNS) dan penuntut umum dalam tahap penyidikan sehingga masing-masing instansi selama ini telah melaksanakan tugas dan fungsinya, tentu saja dengan segala lika-liku serta hambatan dan kendala (baik itu internal maupun eksternal). Namun seiring dengan terus berjalannya sang waktu dan perkembangan jaman, pelaksanaan tugas dan fungsi tersebut tentunya senantiasa

\footnotetext{
${ }^{4}$.Barda Nawawi Arief, Bunga Rampai Kebijakan Hukum Pidana, Bandung : PT. Citra Aditya Bakti, 1996.
} hlm. 74. 
mengalami dinamika permasalahan yang terkadang tidak atau belum diantisipasi oleh hukum, apalagi hukum hanyalah karya manusia yang takkan pernah sempurna.

Permasalahan yang timbul dan tidak diantisipasi / tidak diakomodir oleh hukum, maka para pelaksananya akanberinisiatif mencari solusi dan lama kelamaan akan menjadi praktek kebiasaan yang salah kaprah atau bahkan mengendap dan nantinya endapan itu akan semakin menimbulkan pembusukan didalam sistem. Hal ini tentu saja tidak boleh dibiarkan terjadi terus menerus sebelum sistem itu benar-benar mengalami pembusukan dari dalam yang bisa bermuara pada kegagalan sistem. Oleh karena itu, jika ada subsistem yang diindikasikan telah berjalan secara tidak sehat, seyogyanya ia diperbaiki dan diperbaharui.

Menurut Barda Nawawi Arief ${ }^{5}$, pengertian kekuasaan kehakiman dalam arti luas, maka kekuasaan kehakiman tidak hanya berarti "kekuasaan mengadili" (kekuasaan menegakkan hukum di badan-badan pengadilan), tetapi mencakup kekuasaan menegakkan hukum dalam seluruh proses penegakan hukum. Ini berarti, dalam perspektif sistem peradilan pidana, kekuasaan kehakiman (kekuasaan penegakan hukum) dibidang hukum pidana meliputi seluruh kewenangan/kekuasaan dalam menegakkan hukum pidana, yaitu kekuasaan penyidikan (oleh badan/lembaga penyidik), kekuasaan penuntutan (oleh badan/lembaga penuntutan), kekuasaan mengadili (oleh badan pengadilan) dan kekuasaan pelaksana putusan/pidana (oleh badan/lembaga eksekusi).Keempat tahap kekuasaan kehakiman (di bidang hukum pidana) itulah yang merupakan satu kesatuan sistem penegakan hukum pidana, yang biasa dikenal dengan istilah "sistem peradilan pidana yang terpadu" (integrated criminal justice system).

\footnotetext{
${ }^{5}$ Barda Nawawi Arief, Masalah Penegakan Hukum dan Kebijakan Hukum Pidana dalam Penanggulangan Kejahatan, Jakarta : KencanaPrenada Media Group, 2007. hlm. 34-35.
} 
Secara umum, jika dilihat pada proses pelaksanaan penyidikan yang berjalan selama ini tampak seolah-olah selalu berjalan lancar tanpa terhambat masalah yang berarti, hal ini jika ditilik dari pola hubungan kerja antara Jaksa Penuntut Umum dengan Penyidik Polri dalam rangka penyidikan perkara tindak pidana umum. Namun apabila kita cermati secara lebih mendalam, maka akan ditemui permasalahan yang menurut penulis cukup mengganggu pandangan visioner penulis dalam perspektif perkembangan hukum pidana serta penanganan dan penanggulangan kriminalitas pada waktu yang akan datang.

Isu sentral yang dapat diidentifikasi adalah eksistensi Penyidik Pegawai Negeri Sipil (PPNS) yang tersubordinasi terhadap Penyidik Polri, hal ini telah berjalan lama sehingga menimbulkan implikasi yang fatal terhadap kualitas eksistensi PPNS dan penegakan hukum Administrative Penal Law.Isu sentral ini membawa dampak efek domino kepada permasalahan selanjutnya, yaitu dengan "tertidurnya" PPNS maka penegakan hukum atas pelanggaran tindak pidana tertentu yang bersifat Administrative Penal Law menjadi bertumpu di pundak penyidik Polri. Dengan semakin banyaknya Administrative Penal Lawyang diberlakukan,maka mempelajari hukum pidana dalam undang-undang itu tentu memerlukanwaktu dan pikiran yang banyak.Selain itu dibutuhkan skill intelektualitas dari penyidik yang Sarjana Hukum dan Sarjana Hukum yang penyidik, sementara jumlah penyidik pada instansi kepolisian terbatas.Keadaan ini semakin membuat Polri memperbanyak jumlah penyidik pembantu (berpangkat bintara), yang notabene dari segi kapasitas, kualitas dan kapabilitas pengetahuan hukum pidana kurang dapat terjamin.Dari sudut pandang kepangkatan pun tentu tidak serasi jika ditinjau menurut keseimbangan kepangkatan Penuntut Umum maupun Hakim. Itulah sebabnya sering dijumpai terjadinya bolak-baliknya berkas perkara antara JPU dan penyidik/penyidik permbantu, karena dalam praktiknya yang cukup sering terjadi ialah justru 
penyidik pembantu yang banyak melakukan proses penyidikan dan melakukan pemberkasan.Jangankan untuk penyidikan perkara tindak pidana tertentu, untuk perkara tindak pidana umum pun masih sangat sering dijumpai permasalahan serupa.

Dari gambaran singkat integrated criminal justice system dapat dilihat, berhasil atau tidaknya proses pemeriksaan sidang pengadilan yang dilakukan JPU untuk membuktikan dan menyatakan bahwa terdakwa bersalah, sangat bergantung atas hasil penyidikan. Berkas perkara yang lemah pembuktiannya disebabkan alat bukti yang diajukan penyidik tidak memenuhi batas minimal pembuktian yang digariskan oleh Pasal 183 KUHAP karena :

1. Pada umumnya penyidik lebih cenderung mengumpulkan dan mengajukan alat bukti secara kuantitatif, bukan berdasar kualitatif.

2. Terkadang dari sekian banyak alat bukti yang diajukan, tidak satu pun yang memenuhi syarat formil dan materiil, yang berakibat alat bukti yang diajukan tidak mencapai batas minimal pembuktian, sehingga seluruh alat bukti tersebut tidak mempunyai kekuatan pembuktian ${ }^{6}$.

Seringnya bolak-balik berkas perkara antara Penyidik - Penuntut Umum dapat dimengerti oleh karena berkas perkara yang sering masih belum sempurna sebabJPU menganggap berkas tersebut belum memenuhi syarat formil maupun materiil untuk dilanjutkan ke tahap penuntutan.Hal itu sering terjadi oleh karena 2 hal, pertama karena keterbatasan kemampuan dan kualitas penyidik/penyidik pembantu dalam melakukan penyidikan dan pembuatan berkas perkara; kedua karena pada kenyataannya penyidik pembantulah yang lebih sering melakukan penyidikan dan pembuatan berkas perkara.Tak jarang pula terjadi penyidik ataupun penyidik pembantu yang menyidik suatu tindak pidana yang melanggar

\footnotetext{
${ }^{6}$ R. Soesilo, Taktik dan Teknik Penyidikan Perkara Kriminal, Bogor : Politia, 1989, hlm. 48.
} 
Undang-undang yang bersifat Administrative Penal Lawternyata masih banyak kekurangan dalam pelaksanaan penyidikan dan pembuatan berkas perkaranya.

Di dalam Administrative Penal Law jugamemberi wewenang kepada PPNS pada Kementerian/Lembaga terkait didalam Undang-undang tersebut untuk melakukan penyidikan terhadap tindak pidana yang diatur didalamnya.Sudah seharusnya jika PPNS yang diberi kewenangan menyidik oleh Undang-undang itu lebih memahami dan menguasai, sehingga sebenarnya PPNS dibidang tersebutlah yang seharusnya mengambil inisiatif penyidikan dan tindakantindakan untuk penegakan hukum atas Undang-undang tersebut, dengan demikian tidak hanya menunggu adanya tindakan peniyidikan dari penyidik Polri.

Secara umum dapat digambarkan mengenai kedudukan PPNS, Penyidik Polri dan Penuntut Umum dalam melaksanakan tugas penyidikan adalah sebagai berikut :

1) PPNS kedudukannya berada dibawah "koordinasi" dan "pengawasan" penyidik Polri.

2) Untuk kepentingan penyidikan, penyidik Polri memberikan petunjuk kepada PPNS, dan memberikan bantuan penyidikan yang diperlukan (Pasal 107 ayat 1 KUHAP).

3) PPNS tertentu harus melaporkan kepada penyidik Polri tentang adanya suatu tindak pidana yang sedang disidik (tidak perlu dilaporkan kepada JPU), jika dari penyidikan itu oleh PPNS ada ditemukan bukti kuat untuk mengajukan perkaranya kepada JPU (Pasal 107 ayat 2 KUHAP).

4) Apabila PPNS telah selesai melakukan penyidikan, hasilnya harus diserahkan kepada Penuntut Umum, namun cara penyerahannya dilakukan PPNS "melalui penyidik Polri", Pasal 107 ayat (3) KUHAP. 
Sebelum penyidik Polri meneruskan hasil penyidikan PPNS kepada JPU, penyidik Polri berhak dan berwenang memeriksa dan meneliti berkas perkara tersebut, dan jika dianggap kurang lengkap maka penyidik Polri berhak memberikan petunjuk kepada PPNS untuk melakukan penyidikan tambahan (Pasal 107 ayat 1 KUHAP).

5) Apabila PPNS menghentikan penyidikan yang sebelumnya telah dilaporkan kepada penyidik Polri, maka harus diberitahukan kepada penyidik Polri dan JPU Pasal 109 ayat 3).

Kedudukan PPNS dibawah koordinasi dan pengawasan penyidik Polri yang telah berjalan sekian lama sejak berlakunya KUHAP ternyata mengakibatkan implikasi yang fatal.PPNS menjadi terkesan inferior, tidak percaya diri dalam melaksanakan tugas dan wewenangnya, dan dalam sistem seperti itu yang telah berjalan sekian lama akhirnya mengkerdilkan peran, eksistensi, mental dan kemampuan PPNS.Peran PPNS dalam sistem peradilan pidana masih dikebiri didalam KUHAP itu sendiri, ibarat khiasan "dilepas kepalanya tapi masih dipegangi ekornya" dan masih ditempatkan dibawah ketiak penyidik Polri.

Kementerian yang memiliki PPNS untuk menegakkan dan mengawal pelaksanaan Administrative Penal Law, malah jarang memberdayakan sumber daya manusianya dan makin terbelenggu oleh sistem yang melemahkan mereka secara sistematis.PPNS seringkali dirangkap oleh pejabat yang memangku jabatan struktural strategis dalam organisasi instansinya sehingga mereka lebih sering "mengabaikan" fungsinya sebagai penyidik, mereka lebih mengutamakan pekerjaan rutin sebagaimana jabatan strukturalnya, akibatnya jabatan dan predikat sebagai PPNS hanya diatas kertas saja dengan kemampuan penyidikan yang kurang memadai.

Penyidik Polri berhak dan berwenang memeriksa dan meneliti berkas hasil penyidikan yang dibuat oleh PPNS, dan selanjutnya memberikan petunjuk untuk 
melakukan penyidikan tambahan kepada PPNS.Bukankah itu suatu hal yang memperpanjang rantai birokrasi penanganan perkara?Oleh karena sebenarnya hal itu adalah porsi wewenang JPU dalam tahap prapenuntutan. Misalnya ada suatu kasus yang sudah pernah bolak-balik antara PPNS dengan penyidik Polri, lalu oleh penyidik Polri diteruskan kepada JPU dan ternyata JPU masih menganggap berkas itu belum memenuhi syarat untuk dilanjutkan pada tahap penuntutan, sehingga harus dikembalikan lagi kepada penyidik Polri dan PPNS. Hal ini tentunya sangat bertele-tele dan bertentangan dengan asas penanganan perkara / peradilan yang sederhana, cepat dan murah.

Selain itu, PPNS tertentu harus melaporkan kepada penyidik Polri tentang adanya suatu tindak pidana yang sedang disidik dan tidak perlu dilaporkan kepada JPU, hal ini sudah barang tentu dapat kita rasakan kurang pas dengan prinsip check and recheck di kalangan instansi aparat penegak hukum.

Masih banyak terdapat kekurangan dan tantangan dalam pelaksanaan PPNS, seperti jumlah yang kurang dibandingkan kebutuhan yang tinggi sehingga butuhnya koordinasi tinggi dilapangan baik dengan Polri atau Kantor Wilayah lain, kerap dipandang sebelah mata penegak hukum lain, perkara yang lama disidangkan dan dakwaan lemah sehingga pelaku masih bisa bebas, profesionalitas sebagai penyidik, ${ }^{\mathrm{m}}$ kementerian yang belum ada PPNS sama sekali, keengganan Polri untuk melatih, mutasi PPNS ke posisi bukan penegakan hukum sehingga butuhnya pemetaan, rapat koordinasi dan pelatihan baru, tumpang tindih aturan Undang Undang induk, koordinasi pusat dan daerah, pemahaman seragam terhadap implementasi UU, dan lain sebagainya.

Memang ditinjau dari segi manajemen, pelaksanaan penegakan hukum yang melibatkan beberapa instansi organsisasi dalam proses pelaksanaan sesuai dengan fungsi dan wewenang masing-masing, jelas memerlukan modifikasi pola dan klarifikasi. Namun dalam peningkatan modifikasi pola dan klarifikasi fungsi 
dan wewenang jangan sampai menimbulkan instansi sentris. Setiap instansi aparat harus merupakan subsistem yang mendukung total sistem proses penegakan hukum dalam satu kesatuan yang menyeluruh. Malah mulai dari sekarang harus dipikirkan langkah-langkah pembinaan yang menuju suatu pelembagaan alat-alat kekuasaan penegakan hukum dalam suatu pola law enforcement centre, yaitu suatu lembaga yang menghimpun mereka dalam sistem penegakan hukum terpadu dalam suatu "sentra penegakan hukum". Dalam sentra tadilah berlangsung proses penegakan hukum, mulai dari penyidikan, penuntutan dan peradilan. ${ }^{7}$

\section{Rekonstruksi Dalam Tahap Penyidikan}

Berangkat dari uraian latar belakang tersebut, maka seharusnya posisi dan peran Penyidik Pegawai Negeri Sipil (PPNS) diperkuat dan diberdayakan.Dalam KUHAP, yakni Pasal 6 ayat (2) huruf b, bahwa yaitu pegawai negeri sipil tertentu yang mempunyai fungsi dan wewenang sebagai penyidik yang diberi wewenang khusus oleh Undang-udang. Pada dasarnya wewenang yang mereka miliki bersumber pada ketentuan undang-undang pidana khusus, yang telah menetapkan sendiri pemberian wewenang penyidikan pada salah satu pasal, akan tetapi posisi dan peran PPNS dalam sistem peradilan pidana masih dikebiri didalam KUHAP itu sendiri.

Sudah saatnya dan sudah seharusnya posisi PPNS disejajarkan eksistensi dan kemampuannya dengan penyidik Polri, supaya sistem peradilan pidana kita dapat lebih mengantisipasi tantangan perkembangan jaman dan kriminalitas yang semakin canggih dan kompleks agar berbagai UU yang bersifat Administrative Penal Lawyang dewasa ini semakin banyak diterbitkan dapat ditegakkan apabila terjadi pelanggaran terhadap UU tersebut sehingga tidak

\footnotetext{
7 Abdurrachman, Aneka Masalah Dalam Praktek Penegakan Hukum di Indonesia, Bandung : Alumni, 1984,
} hlm. 56. 
hanya menjadi macan kertas saja. Dari segi kedudukan dan kepangkatan PPNS diatur dalam Peraturan Pemerintah, diselaraskan dan diseimbangkan dengan kedudukan dan kepangkatan penyidik Polri, Penuntut Umum dan Hakim peradilan umum.Hendaknya posisi PPNS sebagai penyidik juga mendapat diferensiasi fungsional yang setara dengan penyidik Polri didalam KUHAP, hanya saja memang wewenang penyidikan yang dimiliki PPNS cuma terbatas sepanjang yang menyangkut dengan tindak pidana yang diatur dalam UU pidana khusus itu. Dari segi kuantitas dan kualitas kemampuan penyidikan dan pembuatan berkas perkara harus selalu ditingkatkan sehingga setiap Kementerian mempunyai PPNS yang berkualitas memadai untuk menegakkan UU yang berlaku di lingkup kewenangannya, terutama UU yang mempunyai sanksi pidana khususnya sehingga apabila terjadi pelanggaran terhadap UU itu maka tidak perlu lagi menunggu-nunggu tindakan dari penyidik Polri,melainkkan PPNS yang mempunyai kewenangan atas UU itu dapat langsung mengambil tindakan penyidikan.

Sebenarnya jabatan PPNS yang seringkali dirangkap oleh pejabat yang memangku jabatan struktural strategis masih bisa dipahami namun sebagai langkah pembaruan dan pembenahan kedepan harusnya pada setiap instansi yang mempunyai PPNS dibentuk suatu unit khusus yang beranggotakan PPNS yang merupakan jabatan fungsional dan para PPNS tersebut mempunyai job description yang khusus hanya untuk melaksanakan fungsi-fungsi PPNS sebagai penegak Undang-undang dibidangnya. Selanjutnya harus ditingkatkan kualitas dan kuantitas dari PPNS tersebut, termasuk sarana dan prasarananya sekaligus dibekali anggaran yang memadai untuk menunjang kinerja dan pelaksanaan tugas-tugas mereka.Sebagai contoh, Kementerian yang sudah melakukan hal tersebut diantaranya Kementerian Lingkungan Hidup dan Kehutanan (PPNS tindak pidana kehutanan, PPNS tindak pidana lingkungan hidup), Kementerian 
Kelautan dan Perikanan (PPNS tindak pidana perikanan), serta Kementerian Keuangan (PPNS tindak pidana perpajakan, PPNS Bea Cukai).

Untuk memberikan solusi dari permasalahan yang telah diuraikan di atas maka perlu dilakukan perombakan tatanan atau hubungan kinerja, yaitu :

1. PPNS harus ditempatkan pada posisi yang setara dengan penyidik Polri secara proporsional dan professional.

2. PPNS mengambil inisiatif penyidikan dan tindakan-tindakan untuk penegakan hukum atas Undang-undang dibidangnya yang memberi wewenang penyidikan kepada PPNS tersebut.

3. Jaksa PU akan bertindak sebagai koordinatordan supervisoryang memimpin jalannya penyidikan antara lain : menentukan pasal-pasal apa saja yang dapat disangkakan kepada tersangka; siapa saja yang dapat dijadikan sebagai tersangka; alat bukti apa saja yang harus dikumpulkan sebagai pembuktian; pengembangan penyelidikan dan penyidikan guna mengungkap secara lebih jauh dari suatu peristiwa pidana, yaitu untuk menemukan calon tersangka lain yang terlibat ataupun aktor/dalangnya serta pasal-pasal yang dapat dikenakan. Namun bukan berarti kedudukan secara fisik dari Jaksa PU dan PPNS maupun Penyidik Polri dibuat dalam satu atap, melainkan hanya dalam satu pola kinerja yang menyatu dimana Jaksa PU sebagai pihak yang memimpin jalannya penyidikan. Dengan demikian lembaga prapenuntutan didalam tata kerja Kejaksaan ditiadakan dan selanjutnya tidak akan lagi terjadi bolak-balik berkas perkara antara Penyidik/PPNS - Penuntut Umum. Dalam tahap penanganan perkara, kerjasama sangatlah mutlak diperlukan diantara Penyidik/PPNS - Penuntut Umum dibawah bimbingan, arahan, koordinasi dan supervisi Jaksa PU.Koordinasi yang terjalin haruslah dalam rangka kesamaan persepsi dalam penanganan suatu perkara pidana agar bisa 
terungkap secara cepat, tepat dan murah dengan tetap mengedepankan penegakan hukum serta memperhatikan kepentingan korban.

4. Kualitas sumber daya manusia harus menjadi perhatian yang serius. Bagi PPNS, penyidik Polri maupun penyidik pembantu haruslah yang berasal dari Sarjana Hukumsupaya mereka mempunyai landasan pengetahuan, wawasan, kemampuan dan intelektualitas di bidang hukum. Bagi Polri maupun Kementerian yang mempunyai PPNS harus menerapkan standarisasi kesarjanaan, jadi bagi yang akan diangkat sebagai penyidik, penyidik pembantu maupun PPNS, gelar Sarjana Hukumnya haruslah dari Perguruan Tinggi Hukum dengan akreditasi A. Beberapa tahun laluada sebuah contoh menarik yang terjadi di kota Palu, Sulawesi Tengah. Terdapat empat orang calon peserta Sekolah Calon Perwira Polri yang sudah lulus tes, namun di Secapa Polri mereka ditolak karena gelar SH mereka berasal dari sebuah Sekolah Tinggi Hukum di kota Palu yang tidak terakreditasi oleh Kopertis Propinsi Sulteng. Padahal Sekolah Tinggi tersebut sebelumnya sudah meluluskan ratusan Sarjana Hukum yang merupakan anggota Polres Palu dan Polda Sulteng, bahkan masih ada ratusan lagi anggota Polres Palu dan Polda Sulteng yang masih berstatus sebagai mahasiswa. Kualitas SDM di bidang penegakan hukum tentunya terkait erat dengan kualitas pendidikan tinggi hukum yang melatarbelakanginya.

5. Bagi PPNS dengan kualifikasi Sarjana Hukum, untuk ketrampilan dan kemampuan penyidikan dapat dipoles di instansi masing-masing. Namun untuk PPNS harus memang harus secara khusus digembleng dengan berbagai pendidikan dan pelatihan untuk dapat memperbaiki keadaan mereka yang sudah terlanjur terjebak dalam ketidakberdayaan. Dan yang paling utama adalah membangun dan menumbuhkembangkan sikap mental dan kepercayaan diri pada diri setiap PPNS bahwa mereka adalah penyidik 
yang mempunyai wewenang penuh atas UU yang berlaku di lingkungan instansi mereka, dan menanamkan persepsi bahwa mereka memang sejajar posisinya dengan penyidik Polri, tidak lagi dibawah pengawasan dan dibawah koordinasi secara subordinat. Selanjutnya harus selalu diciptakan irama kinerja PPNS sebagai penyidik selayaknya kinerja penyidik Polri selama ini, sehingga PPNS tidak akan terulang lagi terjebak dalam kondisi yang sama dengan masa lalunya.

Apabila hal-hal tersebut diatas dapat terwujud maka akan tercipta pembagian kewenangan dan kekuasaan penyidikan secara fair dan lebih profesional sehingga akan memperkecil kemungkinan terjadinya penyimpangan kekuasaan sebagai akibat kewenangan yang terlalu luas pada suatu institusi. Terlalu luasnyakewenangan dan kekuasaan pada satu institusi dalam suatu sistem akan mengakibatkan "pembusukan" sistem itu sendiri sebagai akibat dari arogansi kekuasaan karena merasa sebagai "dewa" yang bisa menentukan nasib kehidupan orang. Sebagaimana ungkapan yang pernah diucapkan Lord Acton :"power tends to corrupt, but absolute power corrupt abolutely".

Begitu pula dengan keadaan perkembangan dinamika masyarakat sekarang ini dimana untuk mengantisipasi tantangan perkembangan jaman dan kriminalitas yang semakin canggih dan kompleks, pemerintah melalui criminal policy-nya telah membuat kriminalisasi dan menuangkannya kedalam berbagai UU sehingga terdapat banyak UU yang berlaku dan yang harus mampu ditegakkan oleh para aparatur Negara. Jika posisi dan peran PPNS telah mendapat diferensiasi fungsional yang setara dengan penyidik Polri didalam KUHAP, mandiri dan independen, berkualitas dengan kuantitas yang memadai pula maka niscaya sistem peradilan pidana akan berjalan dengan lebih sehat untuk menuju kepada tujuan dari sistem peradilan pidana itu sendiri.

\section{Simpulan}


Dari pembahasan diatas, maka dapat diperoleh kesimpulan sebagai berikut :

1. Kedudukan Penyidik PNS, Penyidik Polri dan Penuntut Umum dalam tahap penyidikan yang selama ini dilaksanakan, belum cukup efektif untuk menjamin penegakan hukum guna mendukung efektifitas berjalannya sistem peradilan pidana menuju tercapainya asas peradilan yang murah, cepat dan sederhana. Hal tersebut disebabkan karena :

a) Peran, kedudukan dan wewenang PPNS masih sangat terbatas disebabkan ia berada dibawah pengawasan dan dibawah koordinasi yang dalam prakteknya lebih bersifat subordinat ketimbang kesejajaran. Hubungan antara PPNS dengan JPU pun masih harus disekat oleh penyidik Polri oleh karena adanya ketentuan dalam Pasal 107 ayat 2 KUHAP : "PPNS tertentu harus melaporkan kepada penyidik Polri tentang adanya suatu tindak pidana yang sedang disidik (tidak perlu dilaporkan kepada JPU)". Selanjutnya dalam Pasal 107 ayat 2 KUHAP justru penyidiklah yang melakukan "prapenuntutan" atas berkas hasil penyidikan yang dibuat PPNS, hal ini tentunya akan memperpanjang rantai birokrasi prapenuntutan karena JPU juga akan melakukan prapenuntutan dan akhirnya akan membuat tugas PPNS manjadi semakin rumit dan bertele-tele.

b) Dewasa ini di Indonesia semakin banyak diterbitkan Peraturan Perundangundangan yang bersifat Administrative Penal Law, yang ternyata lebih sering menjadi macan kertas saja. Hal ini dikarenakan penegakan Undang-undang tersebut justru jarang dilakukan oleh PPNS yang diberi wewenang penyidikan oleh Undang-undang itu sendiri, namun lebih sering menunggu dilakukan oleh penyidik Polri yang jumlahnya masih bisa dibilang terbatas jika dibandingkan dengan luas wilayah Negara kita. Masalah lainnya ialahkompleksitas dan tantangan tugas, kendala intern dan ekstern serta begitu banyaknya Administrative Penal Lawdewasa ini, sedangkan keberadaan 
bintara penyidik pembantu tentu saja kurang dapat terjamin kualitasnya. Sinyalemen tersebut dapat dilihat melalui banyaknya berkas perkara yang bolak-balik antarapenyidik dan JPU karena berkas hasil penyidikan belum lengkap atau belum memenuhi syarat untuk dilanjutkan kepada proses hukum selanjutnya, yaitu tahap penuntutan.

c) Seringnya terjadi bolak-balik berkas perkara antara Penyidik - Penuntut Umum hal tersebut dapat dimengerti oleh karena berkas perkara yang masih belum sempurna dan belum memenuhi syarat formil maupun materiil untuk dilanjutkan ke tahap penuntutan. Hal itu sering terjadi oleh karena 2 hal. Pertama, karena keterbatasan kemampuan dan kualitas PPNS dalam melakukan penyidikan dan pembuatan berkas perkara. Kedua, karena pada kenyataannya penyidik pembantulah yang lebih sering melakukan penyidikan dan pembuatan berkas perkara. Penyidik pembantu (berpangkat bintara), yang notabene dari segi kemampuan, pengetahuan hukum dan intelektualitasnya kurang dapat terjamin. Kepangkatan seperti ini tentunya tidak serasi dengan jika ditinjau dari sudut keseimbangan kepangkatan Penuntut Umum maupun Hakim. Itulah sebabnya sering dijumpai penyidikan yang tidak memadai sehingga mengakibatkan sering terjadi bolak-baliknya berkas perkara antara JPU dan Penyidik/Penyidik Permbantu.

d) PPNS seringkali dirangkap oleh pejabat yang memangku jabatan struktural strategis dalam organisasi instansinya sehingga mereka lebih sering "mengabaikan" fungsinya sebagai penyidikdan lebih mengutamakan pekerjaan rutin sebagaimana jabatan strukturalnya, akibatnya jabatan dan predikat sebagai PPNS hanya diatas kertas saja dengan kemampuan penyidikan yang sangat kurang.

2. Mengenai kedudukan Penyidik PNS, Penyidik Polri dan Penuntut Umum, maka yang sebaiknya dilaksanakan untuk dapat menjamin terlaksananya penegakan 
hukum secara efektif menuju tercapainya asas peradilan yang murah, cepat dan sederhana, antara lain :

a) JPU berperan sebagai sebagai pihak yang memimpin penyidikan dan mengarahkan jalannya penyidikan (koordinator dan supervisor), antara lain : menentukan pasal apa saja yang dapat disangkakan kepada tersangka; siapa saja yang dapat dijadikan sebagai tersangka; alat bukti apa saja yang harus dikumpulkan sebagai pembuktian.

b) Setiap Kementerian yang mempunyai PPNS membentuk suatu unit khusus yang beranggotakan PPNS yang merupakan jabatan fungsional dan para PPNS tersebut mempunyai tupoksi yang khusus hanya untuk melaksanakan fungsi-fungsi PPNS. Selanjutnya harus sungguh-sungguh ditingkatkan kualitas dan kuantitas dari PPNS tersebut, termasuk sarana dan prasarananya sekaligus dibekali anggaran yang memadai untuk menunjang kinerja dan pelaksanaan tugas-tugas mereka.Kemudian membangun dan menumbuhkembangkan sikap mental dan kepercayaan diri pada diri setiap PPNS bahwa mereka adalah penyidik yang mempunyai wewenang penuh atas UU yang berlaku di lingkungan instansi mereka, dan menanamkan persepsi bahwa mereka sejajar posisinya dengan penyidik Polri, tidak lagi dibawah pengawasan dan dibawah koordinasi secara subordinat. Selanjutnya harus selalu diciptakan suasana dan irama kinerja PPNS sebagai penyidik selayaknya kinerja penyidik Polri selama ini, sehingga PPNS tidak akan terulang lagi terjebak dalam kondisi yang sama dengan masa lalunya.

c) Revisi terhadap Pasal 7 ayat (2) KUHAP, bahwa PPNS kedudukannya setara dan sejajar dengan penyidik Polri didalam KUHAP, bukan lagi dibawah "pengawasan" penyidik Polri. Mengenai koordinasi tetap diperlukan namun sifatnya bukan sebagai subordinat namun dalam rangka bantuan teknis penyidikan, penangkapan, pencekalan serta bantuan pengamanan . 
d) Pasal 107 ayat (1) KUHAP dihapuskan sebagai konsekuensi bahwa JPU sebagai pihak yang memimpin penyidikan (koordinator $\mathcal{E}$ supervisor) dan tidak ada lagi lembaga prapenuntutan.

e) Revisi terhadap Pasal 107 ayat (2) KUHAP, bahwa PPNS tidak perlu "melaporkan" kepada penyidik Polri tentang adanya suatu tindak pidana yang sedang disidik namun hanya berupa pemberitahuan saja, supaya tidak terjadi tumpang tindih dengan penyidikan yang sudah dilakukan PPNS. Selanjutnya PPNS harus melaporkan kepada Jaksa PU (koordinator dan supervisor)tentang suatu tindak pidana yang sedang disidik, dengan tindasan/tembusan kepada penyidik Polri.

f) Revisi terhadap Pasal 109 ayat (3) KUHAP, bahwa dalam hal PPNS melakukan penghentian penyidikan, pemberitahuannya tidak disampaikan kepada Penyidik Polri namun hanya disampaikan kepada JPU saja dan hal tersebut hanya dapat dilakukan atas persetujuan JPU sebagai pihak yang memimpin penyidikan (koordinator \& supervisor).

g) Revisi terhadap Pasal 107 ayat (3) KUHAP, bahwa apabila PPNS telah selesai melakukan penyidikan, hasilnya harus diserahkan secara langsung kepada Penuntut Umum tanpa "melalui penyidik Polri".

h) Kualitas sumber daya manusia harus menjadi perhatian yang serius. Bagi PPNS, penyidik Polri maupun penyidik pembantu haruslah yang berasal dari Sarjana Hukum lulusan perguruan tinggi dengan akreditasi A, supaya mereka mempunyai landasan pengetahuan, wawasan, kemampuan dan intelektualitas di bidang hukum. Selain itu dalam hal kepangkatan pun akan serasi jika bermitra kerja dengan JPU dan Hakim.

\section{Daftar Pustaka}

Abdurrachman, 1984, Aneka Masalah Dalam Praktek Penegakan Hukum di Indonesia, Bandung : Alumni. 
Ali, Achmad, 2002, Menguak Tabir Hukum (Suatu Kajian Filosofis dan Sosiologis), Jakarta : PT. Toko Gunung Agung Tbk.

Arief, Barda Nawawi, 1998, Beberapa Aspek Kebijakan Penegakan dan Pengembangan Hukum Pidana, Bandung : PT. Citra Aditya Bakti.

Arief, Barda Nawawi, 1996, Bunga Rampai Kebijakan Hukum Pidana, Bandung : PT. Citra Aditya Bakti.

Arief, Barda Nawawi, 2007, Masalah Penegakan Hukum dan Kebijakan Hukum Pidana dalam Penanggulangan Kejahatan, Jakarta : KencanaPrenada Media Group.

Harahap. M. Yahya, 2000, Pembahasan Permasalahan dan Penerapan KUHAP (Penyidikan dan Penuntutan),Jakarta : Sinar Grafika.

Soesilo, R., 1989, Taktik dan Teknik Penyidikan Perkara Kriminal, Bogor : Politia. 